Elçin Marasli

\title{
ORANGE ALTERNATIVE AT THE CONVERGENCE OF PLAY, PERFORMANCE AND AGENCY
}

\author{
Can you treat a police officer seriously, when \\ he is asking you the question: "Why did you \\ participate in an illegal meeting of dwarfs?" \\ Waldemar Fydrych \\ Manifesto of Socialist Surrealism (1980)
}

\begin{abstract}
By observing the mediating role of Pomarańczowa Alternatywa (Orange Alternative), the Polish artistic-activist formation of the $80 \mathrm{~s}$ and $90 \mathrm{~s}$, this paper aims to determine the properties, values and ideals that make a piece of art a public act that can engage people from different social groups in play, and can allow them to reveal their self-determining agency in light of social change. Within the system of varying degrees of social permission, art should allow for the transition from the realm of the "unofficial" to the realm of the "forbidden," and should facilitate a transformation from the realm of thought to the realm of action. Art introduces an element of play into the sphere of collective behavior, and is a bridge over dichotomous social and political forces.
\end{abstract}

Keywords: Orange Alternative, play, agency, performativity, performance art, the public sphere, social activism, values and ideals in art.

\section{ORANGE ALTERNATIVE AT THE CONVERGENCE OF PLAY, PERFORMANCE AND AGENCY}

In this paper, I present a discussion on the Polish artistic-activist formation, Pomarańczowa Alternatywa (Orange Alternative) as an important example of social activism that can mediate between public spheres by use of forms of artistic play and agency. My discussion on Orange Alternative also aims to exam- 
ine the problem of performance art in the context of the Habermasian public sphere and the post-Habermasian counter-publics. Inspired by the definition of art as a certain kind of "performance" with a "specific focus of appreciation,"1 I turn to the case of Orange Alternative with the intention to answer a few other related questions: What can the contemporary public sphere learn from the legacy of this group? Did their artistic legacy deal with transforming the public sphere, or did it remain a performative force of counter-publics? How can their legacy transform the contemporary public sphere today? ${ }^{2}$

I begin to evaluate the Orange Alternative group in the context similar to that introduced in Elzbieta Matynia's treatment of the Polish Solidarity movement, i.e. as a "difficult to categorize" social movement that, however, allowed for "the rebirth of civil society," and that empowered the "agency of selfdetermining citizens." ${ }^{\prime 3}$ I suggest that Orange Alternative represents an artisticperformative genre that blends the notion of free play with the agency of the artist in order to give citizens a self-determining autonomy. I also evaluate the Orange Alternative movement in the context of Matynia's more recent perspective, which reflects upon to the historical approaches by Jürgen Habermas, Henri Lefebvre and Guy Debord. I intend to highlight the movement's relevance to both the contemporary and historical forms of political protest around the world today.

Various samizdat and peculiar techniques employed by Orange Alternative suggest that the group had more to do with counter-publics than with transforming the public sphere itself. The group stood at a point of merging the public sphere with the counter-publics. The social transformative change made possible by Orange Alternative is parallel to the transition from the Habermasian bourgeois public-sphere to the voice of the subordinate groups, from the salons to the streets. Moreover, such a change offers new forms of solidarity and bonding, resulting from a collective experience of being marginalized.

\section{A BRIDGE OVER DICHOTOMIES}

The Orange Alternative movement is, in my view, a considerable artistic victory over the communist regime. Led by its founder and visual artist, Waldemar Fydrych, members of Orange Alternative resorted to graffiti, happenings and samizdat. Those events were frequently studied and referenced by sociolo-

\footnotetext{
${ }^{1}$ Davies, D. 2004. Art as Performance. Oxford: Blackwell.

${ }^{2}$ Davies defines artwork as "a performance that specifies a focus of appreciation," cf. Davies, D. 2004, op. cit., 151. He focuses on the ontological question of what makes art art. In this regard, Davies suggests the main constituent elements are structure and context. On the other hand, I aim to determine a few other constituent variables such as the properties, values and ideals that make a piece of art art, and also, potentially, a socially engaging public act.

${ }^{3}$ Matynia, E. 2001. "The Lost Treasure of Solidarity." Social Research, 68, 4.
} 
gists, anthropologists, art historians, etc. throughout the movement's active years. With roots in Dada and Surrealism, the group's underground campaign ridiculed the social and political condition of the Eastern European situation in the $80 \mathrm{~s}$ and $90 \mathrm{~s} .{ }^{4}$ The group initially started painting dwarves on walls that had been freshly painted to cover up anti-government slogans. Waldemar Major Fydrych and Wiesław Cupała painted the first dwarf in 1982, on one of the residential buildings in the Biskupin neighborhood of Wrocław. ${ }^{5}$ The action soon sparked interest, resulted in more than a thousand dwarf graffiti in Polish cities, eventually led to the arrest of several members, and certainly raised the group to the public forefront. ${ }^{6}$

Even though Orange Alternative is commonly considered standing to the left of the Solidarity movement, it is recognized by various scholars as a bridge across the state and the public, as well as the Party and the Solidarity group. ${ }^{7}$ For those who make far-distance observations on Communist Poland, the spectrum of recognition is quite narrow. Stereotypically, the actors involved are always opposing parties, i.e. the state and the church, the Party and Solidarity, or the state and society etc. Contrary to this mainstream image, the Orange Alternative movement bridges the gap between the dichotomous social and political forces, enriches the sphere of criticism, and introduces a "new quality into the sphere of collective behavior." "This is precisely why Orange Alternative should be considered an important case of social mediator between different public spheres.

\section{FROM THE SALONS TO THE STREETS; THE UNOFFICIAL TO THE FORBIDDEN}

To elaborate on the role of Orange Alternative as a mediator between different social groups in Poland, I briefly review the historical structural transformation of the public sphere. Habermas's key text, "Structural Transformation of the Public Sphere" (1962), deals with the commercialization of cultural relations via the social transition from culture-debating to culture-consuming, hence

\footnotetext{
4 The Official Website of Orange Alternative. Last accessed 14 September 2016; http:// www.pomaranczowa-alternatywa.org/

${ }^{5}$ Fydrych, W. 2014. Lives of the Orange Men-A Biographical History of the Polish Orange Alternative Movement. With a foreword by The Yes Men; http:// www.minorcompositions.info/ ?page id $=24$

${ }^{6}$ Ibid.

${ }^{7}$ Misztal, B. 1992. "Between the State and Solidarity: One Movement, Two InterpretationsThe Orange Alternative Movement in Poland," The British Journal of Sociology, 43, 1, 55-78; Chesters, G., I. Welsh. 2005. "Complexity and Social Movement: Process and Emergence in Planetary Action Systems." Theory, Culture and Society, 22, 5, 144. "Poland's 'Orange Alternative,' a color distinct from both socialist red and Papal yellow, engaged in an extended communal party deploying street theatre and iconic acts such as banner drops. Orange Alternative became a focal point of conversation across Poland."

${ }^{8}$ Misztal, B. 1992, op. cit., 58.
} 
from rational-critical debate to consumerist behavior. ${ }^{9}$ Another major contribution by Habermas is his recognition of the term "public." The public is for him different from the state, the marketplace, and the rather private sphere of family. However, this Habermasian distinction between the "public" and the "private" is embedded with a rather "problematic principle of generality," which results in the exclusion of minority groups from entering into the ideally shared space of the public sphere, as Negt and Kluge argue..$^{10}$ Precisely, this problematic becomes an entry point for future studies on the public sphere and its exclusion of certain groups ("proletarian public sphere," the "subaltern" and "subordinate" groups ${ }^{13}$ ).

The opening of the public sphere to the street begins with developing a new understanding of the relationship between everyday social production and the individual experiences of each different social group. As soon as these counterpublics can begin to tolerate difference and heterogeneity within their own borders, they will be able to form an operational mechanism that can challenge the existing power structures of exclusion. This is precisely the discursive endeavor, the process of bonding and the alliance formation that the notion of the subordinate counter-publics operates upon. Hence, the notion of counter-publics is a rather modern phenomenon, which offers new forms of solidarity and bonding resulting from a collective experience of being excluded and marginalized.

Orange Alternative is a unique example of precisely this form of kinship and solidarity among marginalized groups, formed to overcome their marginalization. Originally coined in reference to the Solidarity movement, the definition of "Aristotelian friendship in times of cultural crisis" by Michael Walzer, can be understood in the context of acts of performative action as transgressive. Likewise, the best entryway into discussing the position of Orange Alternative in engaging the counter-publics via kinship and solidarity is to evaluate the significance of the notion of play. Thus, this notion motivates a change from the realm of personal thought to the realm of collective action. It is also the act through which things evolve from the unofficial to the illegal and the forbidden.

It is reasonable to identify - following Elżbieta Matynia - the Orange Alternative movement as a social development in the realm of forbidden action. Matynia interestingly presents a system of varying degrees of social permission: "In terms of the regime's policies vis-a-vis the population, one can distinguish four kinds of citizen engagement or initiative: the preferred and rewarded; the

${ }^{9}$ Habermas, J. 1965. The Structural Transformation of the Public Sphere: An Inquiry into a Category of Bourgeois Society. The MIT Press, 159.

${ }^{10}$ Kluge, A, O. Negt. 1993. Public Sphere and Experience: Toward and Analysis of the Bourgeois and Proletarian Public. Minneapolis-London: University of Minnesota Press.

${ }^{11}$ Ibid.

12 Warner, M. 2002. Publics and CounterPublics. Zone Books.

${ }^{13}$ Fraser, N. 1990. "Rethinking the Public Sphere: A Contribution to the Critique of Actually Existing Democracy." Social Text, 25/26. 
permitted, but limited; unofficial; forbidden." 14 Thus, the shift from the unofficial to the forbidden is a gradual shift from a realm of dialogue to a realm of action. Orange Alternative represents this shift via happenings and actions that engage the counter-publics with the notion of play, and allow them to reveal their autonomous agency in using action and dialogue interchangeably.

\section{THE NOTION OF PLAY AND THE RIGHT TO THE CITY}

In the case of Orange Alternative, the notion of play is represented by a combination of artistic and political social acts. Likewise, the two historical examples of artistic and political play I refer to here are considered among the driving forces behind the 1968 student uprisings in France. The artistic version of play employed by Orange Alternative members is closest to the notion "dérive" utilized by the Situationist International (SI) and Guy Debord, in particular. "A mode of experimental behavior linked to the conditions of urban society: a technique of rapid passage through varied ambiances. The term also designates a specific uninterrupted period of dériving." ${ }^{15}$ The SI's definition of the "dérive" deals with the notion of play by associating it with the city space. Referring to urban space as a "site of play with psychogeographical effects," Debord's notion of the dérive is among the pioneering modern-day artistic attempts at directly working with the city as a site for play. ${ }^{16}$

Henri Lefebvre's approach to art and art's capacity to fulfill the need for play in social space is worth mentioning here, especially because his view suggests an integration of the notion of play as a right to all inhabitants of the city. By borrowing from "The Production of Space" (1974), we understand that

"[social] space is a [social] product [...] the further claim [is] that the space thus produced also serves as a tool of thought and of action; that in addition to being a means of production it is also a means of control, and hence of domination, or power; yet $[\ldots]$ it escapes in part from those who would make use of it." ${ }^{p 17}$

Lefebvre formulates the right to the city as a transformed and renewed right to urban life, thus presuming an integrated theory of the city and urban life. To do this at best, Lefebvre suggests using resources of science and art. He suggests that art in particular brings to the realization of urban society "its long meditation on life as drama and pleasure."18 "Oeuvre," in Lefebvre's terms,

\footnotetext{
${ }^{14}$ Matynia, E. 2001, op. cit., 920-922.

${ }^{15}$ Definitions of SI terms, SI online; http://www.cddc.vt.edu/sionline/si/definitions.html

${ }^{16}$ Debord, G. 1956. "Theory of the Dérive." In: Les Lèvres Nues, 9.

${ }^{17}$ Lefebvre, H. 1974. "The Production of Space." Nicholson-Smith, D (Trans.). Blackwell, 26.

${ }^{18}$ Lefebvre, H. 1996. "The Right to the City." In: Writings on Cities. Kofman, E., E. Lebas (Eds., Trans.). Cambridge, Mass.: Blackwell, 157-158.
} 
corresponds to "the need for creative activity, information, the imaginary, and most curiously, the need for play."19 Lefebvre recognizes art's special ability to redefine the meaning of "oeuvre" by giving it "multiple facets of appropriated time and space." Thus, art and the history of art are a part of a meditation on the urban, and any social force (i.e. the state) should aim at creating urban society in the form of an "efficient and effective unity of art, technique and knowledge." 20 Orange Alternative's approach is quite close to the combination of these Lefebvrian elements in the form of public performance art that helps bring forth the self-determining agency of its participants and transform their voices into public dialogue as well as counter-public mobility.

The notion of play therefore serves as the link between artistic performance and social political activism. "Can you treat a police officer seriously, when he is asking you the question: "Why did you participate in an illegal meeting of dwarfs?"21 In spite of their sense of humor, Orange Alternative's members were very serious in their endeavors to present Polish citizens with a way of protesting peacefully. They managed to do this by allowing people to regain political agency via the transgressive power of artistic play for social and political change. Through texts such as the Manifesto of Socialist Surrealism (1980), they managed to promote a keen sense of humor that could provide the public sphere with a much-needed self-disciplining agency; if dwarfs could do it, the people will do it! "Pure Rationalism failed to dominate toilets. Surrealism was kept alive in toilets thanks to the politicians [...] The politicians have always been great surrealists." 22

Throughout history governments were frequently trying to ban theatre and other acts of performance, because they believed that the performative genre were capable of spreading and encouraging rebellions against the established order. It is so because performance enables an evaluation of the ways in which individuals act and react in the world, for themselves and for others. From Turner's concept of social drama (1957) to Goffman's dramaturgical model of everyday behavior (1959), anthropological approaches to performance reveal how events, rituals and daily life are governed by a code of performance. Likewise, the notion of performativity (including Butler's "gender performativity,") as a study on the discourse used in identity formation, as well as the performative arts in general, are associated with ideologies connected with performativity in everyday social life. Althusser's notion of the Ideological State Apparatuses (1970), as a driving force that shapes us into subjects that think and behave in socially acceptable ways, should also be mentioned here. These social and political approaches (while it may be assumed that artistic theatrical performances

\footnotetext{
${ }^{19} \mathrm{Ibid}, 147$.

${ }^{20}$ Ibid, 157.

${ }^{21}$ Fydrych, W. 1980. "Manifesto of Socialist Surrealism." Last accessed on 14 September 2016. http://www.pomaranczowa-alternatywa.org/images/manifest-eng-big.jpg

${ }^{22}$ Ibid.
} 
may not directly intend to affect social transformation) can succeed in demonstrating the grounds necessary for change. We can also conclude that the critical potential of change and transformative power lies in the interaction between performance and the audiences. And this is precisely the model through which Orange Alternative appealed to the masses in providing them with an alternative tool for calling forth their own self-determining agency. They did so by means of a kind of performance art that enabled people to merge performativity with an empowering philosophy for social change.

\section{HAPPENINGS AND CARNIVAL}

Orange Alternative succeeded in facilitating social change precisely by presenting a bridge over the artistic agency of performance and the political agency of performativity in building an agency of self-determination on the side of the audience. Through a sense of humor and acts of play, Orange Alternative provided the public sphere with modes of action. The Orange Happenings were most important among them. The movement organized over sixty happenings between the years 1985-1990 in Wrocław, Warsaw, Łódź, and other Polish cities. Orange Alternative's surrealist forms of political activism and the open structure of their happenings recalled Tadeusz Kantor's revolutionary performances in the 1960s. Thanks to this kind of inclusiveness, the happenings could gather thousands of participants in a very short amount of time. The so-called "open street formula" of the Orange Happenings allowed all individuals to participate, openly. The Orange Gathering organized on 1 June 1988, also known as the Revolution of Dwarfs, attracted over ten thousand people who marched through the city center in Wrocław, wearing orange dwarf hats. Their slogans read: "... there is no freedom without dwarfs." 23

Moving along from the happenings, another mode of action that Orange $\mathrm{Al}$ ternative made popular coincided with the notion of the Bakhtinian carnival. The Mexican Zapatista movement as well as various other contemporary activist groups have been actively referencing the concept of carnival as a part of their political agenda: "The revolution in general is no longer imagined according to socialist patterns of realism, that is, as men and women stoically marching behind a red flag, waving flag towards a luminous future: rather it has become a sort of carnival." ${ }^{24}$

The Bakhtinian concept of carnival - which is "a subversion of the established social and political order of things that otherwise appear as fixed and

\footnotetext{
${ }^{23}$ Fydrych, W., 2014, op. cit.

${ }^{24}$ Quote from an anonymous essay, 2003. "Carnival: Resistance is the Secret of Joy." In We Are Everywhere: The Irresistible Rise of Global Anticapitalism. Verso; Online pdf. Last accessed on 23 July 2017; http://artactivism.members.gn.apc.org/allpdfs/173-[essay]Carnival.pdf
} 
unchangeable" - is derived from cultural performances of the late medieval period and the early Renaissance in Europe. ${ }^{25}$ However, the notion of carnival is rather "an overall image of the will of the people," distinguishing it from any social or political structure. ${ }^{26}$ As Bakhtin notes: "Carnival is not a spectacle seen by the people; they live in it and everyone participates because its very idea embraces all the people. While carnival lasts, there is no other life outside it." 27 The image of the Bakhtinian carnivalesque is referred to in numerous fields from stand-up comedy to political demonstrations. There are numerous occasions where Orange Alternative's artistic activism has been argued to display Bakhtin's notion of the "therapeutic force of laughter." 28 Through various elements of street theatre and absurd street painting bordering carnivalesque features, Orange Alternative's actions can be regarded as the pioneers of guerrilla communication and carnival resistance, also commonly practiced in contemporary political protest.

\section{CONTEMPORARY REFLECTIONS}

Orange Alternative's influence on contemporary forms of political protest is undeniable, while their socialist surrealism remains a remarkably artistic form of nonconformist philosophy. With their absurdist yet highly complex social acts, the group's surrealist artistic activism represents a bridge across the Ukrainian Orange Revolution (2004-2005) and the most recent Pastafarian Church of the Flying Spaghetti Monster (FSM). Likewise, it cannot be a mere coincidence that The Yes Men of the United States - creative activists who perform nonviolent resistance by misleading American mainstream media, as well as pulling pranks on major corporations - wrote a foreword to the autobiography by Fydrych, Lives of the Orange Men-A Biographical History of the Polish Orange Alternative Movement (2014).

Contemporary actions by imaginative, aesthetic and self-organizing activist groups such as The Yes Men, Tactical Frivolity, Laboratory of Insurrectionary Imagination, or even individual forms of protest, such as the Duran Adam (Standing Man) of Gezi Park protests and others can best be understood in the context of facilitating social change by merging the artistic agency of performance with the political agency of performativity, hence delivering a selfdetermined agency to the citizens.

\footnotetext{
25 Bakhtin, M. 1984 (1965). Rabelais and His World. Iswolsky, H. (Trans.). Bloomington: Indiana University Press.

${ }^{26}$ Auslander, Ph. 2008. Theory for Performance Studies. A Student's Guide. Routledge.

${ }^{27}$ Bakhtin, M. 1984, op. cit., 7.

${ }^{28}$ The Orange Alternative. Last Accessed 14 September 2016; https://monoskop.org/ Orange_Alternative
} 
Social media represent the hand of globalization taking over anarchist movements at large. Historical reflection upon mass street happenings should not miss out on the value and the contemporary relevance of the non-conformist philosophy of the Polish Orange Alternative movement. The case of Orange Alternative demonstrates the social role of art and particularly performance art at the convergence of the public sphere with the counter-publics. Art should allow for the transition from the realm of the unofficial to the realm of the forbidden. It also should facilitate the transformation from the realm of thought to the realm of action. This can best happen via agency, via play. Art introduces an element of play into the sphere of collective behavior; is a bridge over dichotomous social and political forces and can prove an intermediary across time and space.

\section{REFERENCES}

Althusser, Louis. 1970. "Ideology and Ideological State Apparatuses." In: Lenin and Philosophy, and Other Essays. Brewster, Ben (Trans.). London: New Left Books.

Auslander, Philip. 2008. Theory for Performance Studies. A Student's Guide. Routledge Publishing. Pdf copy last accessed on 14 September 2016; http://www.mohamedrabeea. com/books/book1 13905.pdf

Bakhtin, Mikhail. $198 \overline{4}$ (1965). Rabelais and His World. Iswolsky, Helene (Trans.). Bloomington: Indiana University Press; Pdf copy last accessed on 14 September 2016; http://monoskop. org/images/7/70/Bakhtin_Mikhail Rabelais and His_World 1984.pdf

Bambara, Toni Cade. 2004. Essay \#4 "We Are Everywhere: The Irresistible Rise of Global Anticapitalism." In: Carnival: Resistance is the Secret of Joy,. Last accessed on 14 September 2016. http://www.narconews.com/Issue34/article1097; and http://artactivism.gn.apc.org/ allpdfs/173-[essay]Carnival.pdf

Chesters, Graeme, Ian Welsh. 2005. "Complexity and Social Movement: Process and Emergence in Planetary Action Systems." Theory, Culture and Society, 22, 5, 187-211. Word copy last accessed on 14 September 2016; chrome-extension://gbkeegbaiigmenfmjfclcdgdpima mgkj/views/app.html

Davies, David. 2004. Art as Performance. Oxford: Blackwell.

Debord, Guy. 1956. "Theory of the Dérive." Les Lèvres Nues \#9 (November issue). Last accessed on 14 September 2016; http://www.cddc.vt.edu/sionline/si/theory.html 2000 (1967). Society of the Spectacle. Black \& Red.

Deutsche, Rosalind. 1992. "Art and Public Space: Questions of Democracy." Social Text, issue 33.

Fraser, Nancy. 1990. "Rethinking the Public Sphere: A Contribution to the Critique of Actually Existing Democracy." Social Text, 25/26.

Fydrych, Waldemar. 2014. Lives of the Orange Men-A Biographical History of the Polish Orange Alternative Movement; Pdf copy last accessed on 14 September 2016; http:// www.minorcompositions.info/wp-content/uploads/2014/06/livesoftheorangemen-web.pdf

1980. Manifesto of Socialist Surrealism. Last accessed on 14 September 2016; http://www.pomaranczowa-alternatywa.org/images/manifest-eng-big.jpg

Habermas, Jürgen. 1991 (1965). The Structural Transformation of the Public Sphere: An Inquiry into a Category of Bourgeois Society. Cambridge, Mass.: The MIT Press.

Kluge, Aleksander, Oskar Negt. 1993. Public Sphere and Experience: Toward and Analysis of the Bourgeois and Proletarian Public. Minneapolis-London: University of Minnesota Press. 
Lefebvre, Henri. 1996. "The Right to the City." In: Writings on Cities. Kofman, Eleonore, Elizabeth Lebas (Eds., Trans.). Cambridge, Mass.: Blackwell.

. 1974. "The Production of Space." Nicholson-Smith, Donald. London: Blackwell; https://monoskop.org/images/7/75/Lefebvre_Henri_The_Production_of_Space.pdf;

Matynia, Elzbieta. 2001. "The Lost Treasure of Solidarity." Social Research, 68, 4.

Marasli, Elçin. 2015. "The Orange Alternative-There is no Freedom without Dwarfs." Culture.pl. 22 December 2015 Last accessed on 14 September 2016. http://culture.pl/en/ article/the-orange-alternative-there-is-no-freedom-without-dwarfs

Misztal, Bronislaw. 1992. "Between the State and Solidarity: One Movement, Two Interpretations - the Orange Alternative Movement in Poland." The British Journal of Sociology, 43, 1, 55-78; Pdf copy last accessed on 14 September 2016; http://www. pomaranczowa-alternatywa.org/misztal.pdf

Warner, Michael. 2002. Publics and Counterpublics. Zone Books.

\section{ORANGE ALTERNATIVE ONLINE}

Orange Alternative; Monoskop.org. Last accessed on 14 September 2016; http://monoskop.org/Orange_Alternative

Orange Alternative Official Website. Last accessed on 14 September 2016;

http://www.pomaranczowa-alternatywa.org/

Orange Alternative Virtual Museum. Last accessed on 14 September 2016;

http://www.orangealternativemuseum.pl/\#homepage

ABOUT THE AUTHOR - postgraduate student, School for Social Research at the Institute of Philosophy and Sociology, Polish Academy of Sciences, Nowy Świat 72, 00-330 Warsaw, Poland. Istanbul-born artist and researcher. 2007-2013 she was studying and exhibiting in the United States, 2014-2015 - managing editor of turkiye.culture.pl/ Research interests: comparative study of visual arts, literature and mass media; critical cultural theory; aesthetics; globalism/cosmopolitanism; curatorial practice.

E-mail: elcinmarasli@gmail.com 


\section{DIALOGUE}

AND

UNIVERSALISM 


\section{ADVISORY EDITORIAL COUNCIL}

Leszek Kuźnicki, Eugeniusz Kabatc, Andrew Targowski

Karol Bal, Zdzisław Czarnecki, Stanisław Kowalczyk, Stefan Kozak, Stanisław Krajewski, Józef Lipiec, Józef Niżnik, Marek Rocki, Zofia Rosińska, Zdzisław Sadowski, Henryk Skolimowski, Władysław Stróżewski, Karol Toeplitz, Lech W. Zacher

\section{EXECUTIVE EDITORIAL BOARD}

\section{EDITOR-IN-CHIEF: MAŁGORZATA CZARNOCKA}

Charles Brown (ethics, ecophilosophy, history of philosophy), Stanisław Czerniak (philosophical anthropology, sociology of knowledge), Danilo Facca (history of ancient and modern philosophy) Józef L. Krakowiak (history of modern philosophy, philosophy of culture), Andrzej Leder (psychoanalysis, philosophy of culture), Włodzimierz Ługowski (philosophy of nature), Emily Tajsin (epistemology, semiotics)

ENGLISH LANGUAGE EDITOR: Jack Hutchens WEBSITE: Mariusz Mazurek

\section{The annual subscription (paper copies) rates are:}

Individuals - 44 EUR; as above, for three years in advance - 110 EUR; Institutions - 70 EUR; as above, for three years in advance - 180 EUR

Double copies are available at 12 EUR each for individuals and 20 EUR for institutions; some back issue rates are available on request.

All correspondence concerning the subscription should be sent to (regular mail):

Ars Polona S.A., ul. Obrońców 25, 03-933 Warszawa, POLAND or (email) to: agnieszka.morawska@arspolona.com.pl; malgorzata.podlesna@arspolona.com.pl

Dialogue and Universalism electronic PDF copies are distributed by the Philosophy Documentation Center: order [@] pdenet.org and by Central and Eastern European Online Library (CEEOL)

More information on Dialogue and Universalism may be found on its website: http:// www.dialogueanduniversalism.eu

All editorial correspondence and submissions should be addressed to: e-mail: dialogueanduniversalism@ifispan.waw.pl, or to: Institute of Philosophy and Sociology of the Polish Academy of Sciences, ul. Nowy Świat 72, 00-330 Warszawa, Poland 


\section{VALUES AND IDEALS. THEORY AND PRAXIS}

\section{Part IV}

Edited by Matgorzata Czarnocka and Emily Tajsin

\section{IDEALS AND VALUES IN RELIGION AND MYTH}

Konrad Waloszczyk - On Three Philosophical Premises of Religious

Tolerance

Marshall Steven Lewis - Experimental and Applied Religious Studies for

Reducing Religious Intolerance

Robin S. Seelan SJ - Humanizing and Dignifying Cultures: Dialogues with

Religious Utopias

\section{IDEALS AND VALUES IN ART}

Manjulika Ghosh - Autonomy of Art and Its Value ......................................... 39

C. E. Emmer - Burkean Beauty in the Service of Violence ................................ 55

Tatjana M. Shatunova - Why Be Beautiful? ................................................... 65

Stefan-Sebastian Maftei — The Elusive Sensus Communis of Nowadays Aesthetic Cosmopolitanism ........................................................................ 71

Tetiana Gardashuk — Bioart as a Dialogue ...................................................... 83

Ilektra Stampoulou — Re-framing the Abyss: the Visual Writing of Jacques Derrida in The Truth in Painting

Elçin Marasli - Orange Alternative at the Convergence of Play, Performance and Agency

\section{VALUES AND IDEALS IN SCIENCE AND VALUE OF SCIENCE}

Vladimir Przhilenskiy - Theoretical and Post-Theoretical Philosophy

Matgorzata Czarnocka - The Ideal and Praxis of Science

Giovanni Boniolo, Mattia Andreoletti, Federico Boem, Emanuele Ratti - The 
Martha C. Beck- Neuroscience, Ancient Wisdom and the ISUD:

Is There Anything New under the Sun?

Maria Kli - The Ethical and Political Significance of Michel Foucault's

Ancient Technology of the Care of the Self

Mikhail A. Pronin - Dialogue as a Knot: The First Ideas of Dialogue

Ontology 203

Anna Ivanova - The Trustworthiness of Science. Toward an Axiological Notion of Scientific Objectivity 